minorities have long since given way

1620: A Critical Response to the 1619

Project, Peter W. Wood, Encounter, 2020, pp. 262, \$28.99 hardcover.

\section{Critical Race Theory and the Will to Power}

\author{
Bruce P. Frohnen
}

For decades now, Americans have struggled over how they should understand their country and themselves as a people-indeed, whether they should understand themselves as a people at all. In a large, free, and diverse nation such struggles usually are as beneficial as they are inevitable. Such benignity requires, however, that all sides engage with substantial amounts of honesty and goodwill, lest comity and social trust give way to resentment and the will to power, with catastrophic results for our freedoms and our humanity. Unfortunately, in America attempts to expand the teaching of history to include formative stories of women, immigrants, and racial and other to a determination to highlight our nation's dark side. Textbooks from primary through graduate school now emphasize the injustices done to specific groups in a manner designed to undermine Americans' pride in country and people. The growth of Critical Race Theory especially has intensified this struggle as its proponents have worked to "reimagine" America as a fundamentally racist regime. On this view, Americans' pretensions to liberty and justice for all should be dismissed as mere cant and our constitutional government should be replaced by a system in which those with institutional power in government, corporate HR departments, schools, and elsewhere bestow "reparations" and life-chances according to their perception of relative victimhood.

This struggle reached a new level with the 1619 Project, a multi-platform campaign launched by the New York Times and the Pulitzer Center for Crisis Journalism that has been propounded by journalists, academics, activists, and teachers utilizing lesson plans offered free to school districts throughout the country. As Wood points out, the 1619 Project is an "all-out effort to replace traditional

Bruce Frohnen is Professor of Law, Ohio Northern University College of Law; b-frohnen@onu.edu. He is the author, with George W. Carey, of Constitutional Morality and the Rise of Quasi-Law (Harvard University Press, 2016) and, with Ted V. McAllister, of Coming Home: Reclaiming America's Conservative Soul (Encounter, 2019). 
conceptions of American history with

a history refracted through the lens of black identity politics." It would restructure American education around the claim that America was founded on, prospered through, and has systematically furthered white supremacy.

At this late date, after several generations of multicultural education, with school districts in most major cities already integrating Black Lives Matter and other race-based programs into their curricula, and in the face of a national regime committed to the propagation of race-based public policy, one might be forgiven for asking how, if at all, such a program is to be countered.

In one sense the answer is quite complex. The 1619 Project is audacious and expansive. It is a set of factual claims and claims regarding the nature of history itself. It is also a political program, an academic and educational campaign, and an institutional movement serving the interests of administrators in government, education, and business. Wood knows this. But the greatest strength of this important book rests on his recognition of a more simple, basic duty: to tell the truth about our history and to oppose, wherever possible, those who hate our way of life and seek to bully the rest of us into living by lies.
As to the facts, the 1619 Project, from its inception in a special issue of the New York Times Magazine, has made several crucial claims: first, America's fundamental origins, from which our entire history and character have derived, lie in the arrival of slaves in Virginia in 1619; second, Americans fought their War for Independence out of fear that the British would outlaw slavery; third, American capitalism was founded on and continues to be shaped by relations rooted in plantation slavery; fourth, African Americans were friendless and alone, with no allies in their struggles for civil and human rights; and, fifth, that Abraham Lincoln was a racist who worked to maintain racial separation and the subjugation of African Americans.

Taken together, these claims paint a picture of America as a system and a people wholly devoted to white supremacy. As such, they are a demand that America be, not merely reformed, but fundamentally transformed according to the dictates of racial identity politics. Wood properly notes that the result would be harmful for liberty, self-government, “and our virtues as a people." He also recognizes that "little is to be gained ... by progressives and conservatives lobbing boulder-sized principles back and forth across the line that divides 
them." And so, this book works to return readers' attention to relevant historical facts and, as important, to highlight the fundamentally dishonest manner by which those behind the 1619 Project have worked to undermine the forms of discourse necessary to adjudicate such claims and allow we the people to judge their veracity.

In a relatively few, comprehensible pages, Wood tells the truth about the arrival of Africans in Virginia in 1619-aboard a diverted pirate ship, "exchanged" for food from the colonists. These unfortunate people were kept as indentured servantsan unjust status still far preferable to that of slaves-because the colonists refused to regularize slavery in 1619 or for decades afterward. Wood also gives a brief but compelling review of a far more influential candidate for America's founding moment: the 1620 promulgation of the Mayflower Compact. With this document Pilgrims about to land in the New World joined with non-Pilgrim shipmates (recruited by the London Merchant Adventurers to build a colony in northern Virginia) to devote themselves to the pursuit of the common good under law. The individual dignity and common purpose fostered by their Compact aided the colonists as they entered a world of many dangers, both complicated and made easier by pre-existing tensions among the native Americans. Wood takes apart the 1619 Project's other central claims as well. His refutation is fact-based and compelling, showing quite clearly that slavery is not and has never been central to American development, except in the sadly ironic sense that it lay behind our most tragic conflicts, in particular the Civil War.

But 1620 is not primarily a counter-history. Its intent is to respond to the 1619 Project as a campaign, not to revisit in comprehensive fashion the broad themes of American history and identity. Others have written extensively on these topics, the most recent comprehensive volume being Wilfred McClay's Land of Hope. Moreover, as Wood reviews, serious contemporary scholars have shown that the 1619 Project's central claims are based in shoddy scholarship, innuendo, and simple, counter-factual assertions.

Wood's broader purpose stems from the sad fact that the 1619 Project continues to wield influence among our elites and to shape the education of our young people. How can such shoddy work exert so much power? The crux of the issue is bad faith, enabled by the decay of basic standards of intellectual rigor and public discourse. As Wood notes, "The usual way for disputes about history to be 
resolved is for historians to present their best arguments, and their sources, in journal articles; each side can then examine the evidence for themselves and hammer out the truth. The 1619 Project evades this kind of transparency." Instead, the journalist Nikole Hannah-Jones and her 1619 collaborators eschew meaningful citations, reasoned argument, and even civil responses to their critics, choosing instead the path of evasion, invective, and grandstanding. For example, Hannah-Jones made a series of factual claims at the Project's inception, including that 1619 was America's founding and that the 1619 Project should replace then-existing history teaching. Now that her facts and model of teaching have received significant fact-based criticism from noted historians, she flatly (mis)states that she never made either claim. Her other responses to fact-based criticisms have included rude gestures made via social media and denials that facts are central to the study of history. Instead, she now says, the point of history is to impart wider, narrative "truths" presumably aimed at enlightening people through the power of ideology-based myths.

This last iteration of HannahJones's "defense" of her project is the most troubling and important because it has become a new orthodoxy in academia, journalism, and increasingly, public life. New York Times Magazine editor in chief Jake Silverstein, for example, has dismissed criticisms of the 1619 Project and refused to correct its many glaring inaccuracies with the facile claim that "[h]istorical understanding is not fixed; it is constantly being adjusted by new scholarship and new voices." Sadly, the voices of the 1619 Project are not new; for some years they have been the ruling voices of journalism and the academy. How else explain The American Historical Review's circulation of a statement by its editor, Alex Lichtenstein (a professor of history at Indiana University) titled "1619 and All That." As its title indicates, the statement is a dismissal of the myriad criticisms noted historians from Gordon Wood to James McPherson have made of the 1619 Project. Lichtenstein asserts that the "reframing" of the country's 'origins' was a rhetorical move, one that impressed upon a wider public an interpretative framework that many historians probably already accept-namely, that slavery and racism lie at the root of "nearly everything that has made America exceptional."”

True to his convictions, Lichtenstein notes that in his own undergraduate teaching he emphasizes that "the African American 
experience must be considered central to every aspect of American history." "Every aspect" of American history is to be interpreted through the lens of one racially-defined group's experience, which itself is reduced to the experience of and resistance to racism. No wonder Lichtenstein finds the 1619 Project's orientation "laudable, if unexceptional." As Wood notes, the $A H R$ 's publication of this statement provides "a kind of permission slip to thousands of other professional historians to ignore the controversy" over the 1619 Project's misstatements "as unworthy of their time and attention." Indeed, those who openly criticize the project risk their own professional standing because "all these historians are white" (one of Lichtenstein's factual misstatements) hence morally suspect, at best.

Unfortunately,

Lichtenstein speaks not only for the majority of American historians, but also for those in positions of power within higher and K-12 education. As Wood reviews in detail, the 1619 Project aims to influence teachers and textbook writers to further radicalize the teaching and understanding of America institutionalized in public and elite schools. Little resistance can be expected from an academy, like ours, where conservative voices are essentially nonexistent and moderate voices are so overwhelmed that it is often left to old style Marxists to defend basic reality from the fanciful claims of CRT.

We are left, then, with the same marginalized figures and voices that have been speaking out for decades against radicals whose bureaucratic skills and will to power have gained them mastery over administrative structures in education, government, business, and culture. The question is whether the 1619 Project marks the culmination of the march through the institutions toward establishment of a new, race-based orthodoxy that will rule every aspect of our lives, or whether its radical rejection of basic facts represents a bridge too far such that reasoned argument and determined resistance, especially in our local school districts, can turn them back and re-establish an openness toward truth in history. 